\title{
Analisis Tingkat Pertumbuhan Wajib Pajak Orang Pribadi Dan Penerimaan Pajak Penghasilan Setelah Ditetapkannya Peraturan Menteri Keuangan Nomor 101/PMK.010/2016 Tentang Penyesuaian Besarnya Penghasilan Tidak Kena Pajak (Study Pada KPP Pratama Sidoarjo Barat)
}

\author{
Rachyu Purbowati ${ }^{1}$, Rizki Fitriana Lestari ${ }^{2}$ \\ STIE PGRI Dewantara Jombang
}

Korespondensi : rachyupurbowati@yahoo.com

\begin{abstract}
Abstrak
Dalam UU No. 7 tahun 1983 yang terakhir kali diubah menjadi UU No.36 Tahun 2008 tentang Pajak Penghasilan, disebutkan bahwa kepada orang pribadi atau perseorangan sebagai Wajib Pajak dalam negeri diberikan pengurangan berupa PTKP. Penelitian ini dimaksudkan untuk mengetahui tingkat pertumbuhan Wajib Pajak orang pribadi dan penerimaan pajak penghasilan pada KPP Pratama Sidoarjo Barat setelah ditetapkannya PMK No. 101/PMK.010/2016 tentang Penyesuaian Besarnya Penghasilan Tidak Kena Pajak. Metode penelitian dalam penelitian ini adalah metode penelitian kualitatif deskriptif. Informan dalam penelitian ini adalah Kepala Seksi Pemeriksaan dan Kepala Seksi Pengawasan dan Konsultasi 3 KPP Pratama Sidoarjo Barat. Dari hasil penelitian, diketahui bahwa tingkat pertumbuhan Wajib Pajak setelah ditetapkannya PMK No. 101/PMK.010/2016 Tentang Penyesuaian Besarnya Penghasilan Tidak Kena Pajak terus mengalami peningkatan selama dua tahun terakhir. Begitu pula realisasi penyampaian SPT yang juga terus mengalami kenaikan selama dua tahun terakhir. Namun, pertumbuhan jumlah Wajib Pajak ini bukanlah berasal dari perubahan PTKP. Ada beberapa faktor lain yang mampu meningkatkan jumlah Wajib Pajak seperti munculnya Wajib Pajak baru. Penerimaan Pajak Penghasilan pada KPP Pratama Sidoarjo Barat juga terus meningkat setelah ditetapkannya PMK No. 101/PMK.010/2016 Tentang Penyesuaian Besarnya PTKP. Peningkatan penerimaan PPh Pasal 21 pada KPP Pratama Sidoarjo Barat mengalami kenaikan hingga lebih dari $20 \%$.
\end{abstract}

Kata Kunci : Penghasilan Tidak Kena Pajak, Pertumbuhan Wajib Pajak, Penerimaan Pajak.

\begin{abstract}
In Law No. 7 of 1983 which was last changed to Law No.36 of 2008 concerning Income Tax, An individual who is a resident Taxpayer is entitled to claim personal exemptions. This study is intended to determine the growth rate of personal taxpayers and income tax revenue at the KPP Pratama Sidoarjo Barat after the stipulation of PMK No. 101 / PMK.010 / 2016 concerning Adjustment of Non-Taxable Income. The research method in this study is descriptive qualitative research method. The informants in this study were the Head of the Inspection Section and the Head of Supervision and Consultation Section 3 of KPP Pratama Sidoarjo Barat. From the results of the study, it is known that the taxpayer's growth rate after the stipulation of PMK No. $101 /$ PMK.010 / 2016 concerning Adjustment of PTKP amount continues to increase over the last two years. As well as the realization of the SPT submission which also continued to increase over the past two years. However, the growth in the number of taxpayers is not derived from changes in PTKP. There are several other factors that can increase the number of taxpayers, such as the emergence of new taxpayers. Income Tax Revenue at the KPP Pratama Sidoarjo Barat also continued to increase after the stipulation of PMK No. 101 / PMK.010 / 2016 concerning Adjustment of Non-Taxable Income. The increase in PPh Article 21 revenue at the KPP Sidoarjo Barat has increased to more than 20\%.
\end{abstract}

Keyword : Non Taxable Income, growth rate of personal taxpayers, tax revenue

\section{A. Pendahuluan}

Semua negara pasti ingin masyarakatnya hidup dengan sejahtera, tak terkecuali bangsa Indonesia. Beragam strategi bakal dilakukan pemerintah guna terwujudnya kesejahteraan masyarakat, salah satunya dengan memaksimalkan pembangunan infrastruktur. Demi mengantongi pasokan dana yang nilainya tidak sedikit itu, pemerintah dirasa perlu untuk menaikkan pendapatan negara. Untuk mendongkrak pendapatan negara di sektor penerimaan perpajakan dan penerimaan perpajakan perlu diaplikasikan strategi optimalisasi (Aditia : 
2013). Penerimaan pajak menjelma sebagai elemen kunci dalam pendapatan negara. Tanpa pajak, kehidupan negara akan terpuruk dan tidak mampu berjalan dengan mulus (Muhammad Iqbal, 2015, http://www.pajak.go.id/content/artic le.pajak-sebagai-ujun-tombakpembangunan, 15 Januari 2018). Pajak menjadi kunci utama penerimaan negara. Apabila pajak dihapuskan, maka seluruh aktivitas negara akan terhambat. Hal ini lantaran di dalam pajak terkandung dua fungsi yang terikat yaitu fungsi budgeter dan fungsi reguler.

Disebutkan dalam pasal 1 UU No.28 tahun 2007 tentang Perubahan Ketiga atas UU No. 6 tahun 1983 tentang Ketentuan Umum dan Tata Cara Perpajakan, bahwa pajak merupakan kontribusi wajib kepada negara yang terutang oleh orang pribadi atau badan yang bersifat memaksa berdasarkan Undang-Undang, dengan tidak mendapatkan imbalan secara langsung dan digunakan untuk keperluan negara bagi sebesar-besarnya kemakmuran rakyat. Pada tahun 2018, pemerintah mematok penerimaan pajak sejumlah Rp 1.618,1 triliun dalam APBN 2018. Nilai tersebut jumlahya 9.9\% lebih tinggi ketimbang tahun 2017 yang besarnya hanya $\mathrm{Rp} 1.472,7$ triliun.

Tabel 1. Perbandingan Pendapatan Negara Tahun 2017 dengan APBN 2018

\begin{tabular}{lll}
\hline \multicolumn{1}{c}{ Sumber Pendapatan Negara } & \multicolumn{1}{c}{ Pendapatan Negara Tahun } & \multicolumn{1}{c}{ APBN 2018 } \\
\hline Pendapatan Dalam Negeri & Rp 1.733,0 triliun & Rp 1.893,5 triliun \\
Penerimaan Perpajakan & Rp 1.472,7 triliun & Rp 1.618,1 triliun \\
Penerimaan Negara Bukan Pajak & Rp 260,2 triliun & Rp 275,4 triliun \\
Penerimaan Hibah & Rp 3,1 triliun & Rp 1,2 triliun \\
\hline
\end{tabular}

sumber : informasi APBN 2018, telah diolah

Penyumbang terbesar dalam target penerimaan perpajakan di tahun 2018 masih diduduki oleh pajak penghasilan. Hampir sekitar 53\% dari total penerimaan perpajakan bersumber dari pajak penghasilan. Penyumbang terbanyak kedua, sebesar $32 \%$ bersumber dari Pajak Pertambahan Nilai. Kenaikan PPN ini seirama dengan upaya pemerintah untuk mendongkrak konsumsi rumah tangga. Sedangkan sisanya sejumlah $15 \%$ dihasilkan oleh Pajak Bumi Dan Bangunan, cukai, bea masuk, bea keluar dan pajak lainnya. (Informasi APBN 2018, 2018)

Untuk menambah penerimaan pajak, pemerintah tentu mempunyai strategi-strategi khusus, mulai dari meningkatkan mutu pelayanan terhadap Wajib Pajak melalui kemudahan pelaporan, pembayaran, dan memberikan kemudahan akses informasi perpajakan, perubahan tarif pajak, hingga menaikkan besaran PTKP. Kepatuhan wajib pajak, pemeriksaan pajak, peningkatan PTKP dan kebijakan sunset policy jilid 2 merupakan sebagian elemen yang memberikan pengaruh pada penerimaan pajak (Wulandari, 2015). Penghasilan Tidak Kena Pajak (PTKP) memberikan kontribusi penting dalam pemotongan PPh 21, karena untuk menetapkan PKP, penghasilan neto harus dikurangi PTKP terlebih dahulu. Selain itu tambahan PTKP akan diberikan pada WP yang berumah tangga, ataupun yang memiliki tanggungan saudara sedarah maupun semenda.

Kebijakan pemerintah tentang jumlah Penghasilan Tidak Kena Pajak kerap berubah mengikuti perkembangan jaman. Kebijakan mengenai besaran PTKP yang berjalan sekarang adalah Peraturan Menteri Keuangan Nomor 101/PMK.010/2016 tentang Penyesuaian Besaran Penghasilan Tidak Kena Pajak. PTKP yang awalnya sejumlah Rp 36.000.000, mengalami kenaikan menjadi Rp 54.000.000. WP yang berkeluarga maupun yang memiliki tanggungan keluarga sedarah ataupun semenda naik menjadi senilai Rp 4.500.000 yang sebelumnya hanya senilai Rp 3.000.000. Peningkatan besaran PTKP ini tentu bukan tanpa alasan khusus. Pemerintah tentu memiliki tujuan tersendiri dalam menetapkan kebijakan 
penyesuaian PTKP. Bambang Brodjonegoro, Menteri Keuangan di kala itu menegaskan bahwa peningkatan PTKP di tahun 2016 dilakukan agar pertumbuhan ekonomi dan juga konsumsi rumah tangga bisa meningkat (Fiki Ariyanti, 2016, http://m.liputan6.com/amp/2477210/alasan-gaji-rp-45-juta-per-bulan-bebas-pajak,5 Januari 2018). Melalui kebijakan ini, pemerintah berambisi untuk sanggup mendongkrak daya beli masyarakat.

Namun apabila ditelaah, dengan meningkatnya PTKP, penerimaan pajak PPh 21 justru akan menurun. Hal itu karena banyaknya pajak yang dipikul Wajib Pajak jumlahnya akan lebih sedikit dibandingkan dengan PTKP yang diberlakukan sebelumnya. Namun, disisi lain, dengan meningkatnya PTKP, secara spontan akan berimbas terhadap peningkatan jumlah penerimaan Pajak Pertambahan Nilai dan PPN-BM. Hal ini selaras dengan misi pemerintah untuk mendorong daya beli masyarakat serta meningkatkan konsumsi rumah tangga, karena apabila barang yang dibeli masyarakat semakin membludak, maka Pajak Pertambahan Nilai yang dibebankan pada masyarakat juga akan semakin meningkat, yang artinya penerimaan pajak secara otomatis juga akan meningkat. Tidak hanya itu, dengan meningkatnya PTKP seharusnya bisa mendorong masyarakat menjadi makin taat untuk membayar pajak, karena pajak yang dibebankan nilainya tidak sebesar sebelumnya. Sehingga semakin banyak Wajib Pajak yang taat dan tepat waktu membayar pajak, maka akan semakin banyak pula penerimaan pajak yang terserap Kas Negara.

Penyesuaian PTKP bukan hanya berpengaruh pada penerimaan pajak, karena PTKP merupakan pengurang dari penghasilan neto, sehingga akan didapatkan hasil Penghasilan Kena Pajak (PKP). PKP inilah yang dijadikan patokan untuk memutuskan besarnya pajak yang dikenakan kepada Wajib Pajak. Hal ini memicu permasalahan ketika Wajib Pajak yang berpenghasilan lebih rendah dari PTKP, karena menurut PMK No.243/PMK.03/2014 tentang Surat Pemberitahuan Pajak bahwa Wajib Pajak Orang Pribadi yang berpenghasilan tidak lebih dari besaran PTKP dikecualikan atau tidak diwajibkan untuk menyampaikan SPT Tahunan. Sehingga tentunya hal tersebut akan mempengaruhi tingkat pertumbuhan Wajib Pajak.

Penelitian ini menindaklanjuti penelitian Nafia dan Sunandar di tahun 2016 dengan judul "Analisis Perbedaan Penerimaan Pajak Penghasilan Sebelum dan Sesudah Kenaikan Penghasilan Kena Pajak (PTKP) Pada Kantor Pelayanan Pajak Tegal" dimana penelitian ini memperoleh hasil bahwa ditemukan selisih jumlah penerimaan Pajak Penghasilan Pasal 21 antara sebelum dan sesudah pertambahan besaran PTKP yaitu di tahun 2011 KPP Pratama Tegal menerima pajak penghasilan sejumlah Rp 39.458.757.629 sedangkan di tahun 2012 sejumlah Rp 48.658.611.591. Yang memberikan perbedaan penelitian ini dari penelitian sebelumnnya adalah penelitian sebelumnya masih menggunakan dasar PMK No.162/PMK.011/2012, sedangkan penelitian ini berpedoman pada kebijakan terbaru yakni PMK No.101/PMK.010/2016.

Selain dasar acuan yang berbeda, perbedaan yang lainnya terlihat dari variabel penelitian, dimana penelitian sebelumnya hanya fokus pada penerimaan pajak saja. Selain itu, pemilihan objek penelitian juga berbeda, penelitian sebelumnya dilaksanakan di KPP Pratama Tegal, sedangkan penelitian ini dilaksanakan di KPP Pratama Sidoarjo Barat. Namun, ada pula persamaan antara penelitian ini dengan penelitian sebelumnya yakni samasama meneliti perihal penerapan kebijakan besaran PTKP. Observasi ini mengambil objek penerimaan pajak dan tingkat pertumbuhan wajib pajak di KPP Pratama Sidoarjo Barat. Adapun tujuan penelitian ini adalah untuk memahami dampak dari ditetapkannya PMK No.101/PMK.010/2016 tentang Penyesuaian Besarnya PTKP terhadap tingkat pertumbuhan Wajib Pajak di KPP Pratama Sidoarjo Barat dan dampak dari ditetapkannya PMK No.101/PMK.010/2016 tentang Penyesuaian Besarnya PTKP terhadap penerimaan pajak di 
KPP Pratama Sidoarjo Barat dampak dari ditetapkannya PMK No.101/PMK.010/2016 tentang Penyesuaian Besarnya PTKP terhadap penerimaan pajak di KPP Pratama Sidoarjo Barat.

\section{B. LANDASAN TEORI}

\section{Pengertian Pajak dan Wajib Pajak}

Soemitro (dalam Resmi, 2013 : 1) menegaskan bahwa yang disebut dengan pajak ialah iuran rakyat yang dibayarkan ke Kas Negara dengan berdasarkan pada Undang-Undang yang berlaku serta dapat dipaksakan serta tidak meraup timbal balik secara langsung yang bisa dinikmati oleh masyarakat, dan dimanfaatkan pemerintah untuk mendanai pengeluaranpengeluaran umum. Pasal 1 UU No. 28 tahun 2007 tentang Perubahan Ketiga atas UU No. 6 tahun 1983 tentang Ketentuan Umum dan Tata Cara Perpajakan, Wajib Pajak ialah orang pribadi atau badan, meliputi pembayaran pajak, pemotong pajak, pemungut pajak, yang mempunyai hak dan kewajiban perpajakan sesuai dengan ketentuan peraturan perundangundangan perpajakan.

\section{Syarat Subjektif Dan Objektif Pajak}

Persyaratan subjektif pajak adalah persyaratan yang sesuai dengan ketentuan mengenai subjek pajak dalam Undang-Undang Pajak Penghasilan No. 7 Tahun 1983 yang terakhir kali diubah menjadi UU No.36 Tahun 2008. Sedangkan persyaratan objektif merupakan persyaratan bagi subjek pajak yang menerima ataupun memperoleh penghasilan atau yang diwajibkan untuk melakukan pemotongan/pemungutan sesuai dengan ketentuan UndangUndang Pajak Penghasilan No.7 tahun 1983 yang terakhir kali diubah menjadi UU No.36 Tahun 2008. Menurut UU No. 36 Tahun 2008 Tentang Perubahan Keempat atas UU No. 7 Tahun 1983 mengenai Pajak Penghasilan,yang menjadi subjek pajak adalah :

a. Orang pribadi

b. Warisan yang belum terbagi

c. Badan

d. Bentuk usaha tetap.

Subjek pajak didistribusi menjadi dua, yaitu subjek pajak dalam negeri dan subjek pajak luar negeri.

Yang dimaksud dengan objek pajak adalah :

a. Penghasilan, yakni setiap tambahan kemampuan ekonomis yang diterima dan diperoleh Wajib Pajak, baik yang berasal dari Indonesia maupun dari luar Indonesia, yang dapat digunakan untuk konsumsi atau untuk menambah kekayaan Wajib Pajak, dengan nama dan dalam bentuk apa pun, diantaranya :

1. Imbalan yang berhubungan dengan pekerjaan atau jasa yang diterima dan diperoleh Wajib Pajak termasuk gaji, tunjangan, upah, honorarium, bonus, komisi, gratifikasi, uang pensiun, maupun imbalan dalam bentuk lainnya.

2. Hadiah yang berasal dari undian maupun hadiah atas pekerjaan atau kegiatan tertentu.

3. Laba usaha.

4. Keuntungan dari kegiatan penjualan atau dikarenakan pengalihan harta.

5. Penerimaan kembali pembayaran pajak yang sudah dibayarkan sebagai biaya dan pembayaran tambahan pengembalian pajak.

b. Adapun penghasilan yang merupakan pajak final,diantaranya :

1. Penghasilan yang berbentuk bunga deposito dan tabungan, bunga obligasi, surat utang negara, dan bunga simpanan yang dibayarkan oleh koperasi kepada anggota koperasi orang pribadi.

2. Penghasilan yang diperoleh dari hadiah undian. 
3. Penghasilan dari transaksi saham dan sekuritas lainnya, transaksi derivatif di bursa, dan transaksi penjualan saham maupun pengalihan penyertaan modal pada perusahaan pasangannya yang diterima oleh perusahaan modal ventura;

4. Penghasilan dari transaksi pengalihan harta berupa tanah dan/atau bangunan, usaha jasa konstruksi,usaha real estate, dan penyewaan tanah dan/atau bangunan

\section{Penghasilan Tidak Kena Pajak}

Dalam UU No. 7 tahun 1983 yang terakhir kali diubah menjadi UU No.36 Tahun 2008 tentang Pajak Penghasilan, disebutkan bahwa kepada orang pribadi atau perseorangan sebagai Wajib Pajak dalam negeri diberikan pengurangan berupa Penghasilan Tidak Kena Pajak. Seiring berjalannya waktu, nilai Penghasilan Tidak Kena Pajak selalu berubah-ubah dari masa ke masa mengikuti perkembangan zaman. Revisi terbaru mengenai PTKP yaitu PMK No. 101/PMK.010/2016 tentang Penyesuaian Besarnya Penghasilan Tidak Kena Pajak, yang menunjukkan peningkatan jumlah PTKP pada Wajib Pajak Orang Pribadi. Penyesuaian besarnya PTKP menjadi :

a. Wajib Pajak Orang Pribadi memperoleh PTKP senilai Rp 54.000.000.

b. Wajib Pajak yang sudah berkeluarga mendapat tambahan PTKP senilai Rp 4.500.000.

c. Bagi istri yang melakukan pekerjaan dan berpenghasilan sendiri, serta penghasilannya digabungkan dengan penghasilan suami memperoleh tambahan senilai Rp 54.000.000.

d. Untuk Wajib Pajak yang mempunyai tanggungan anggota keluarga dengan garis keturunan lurus baik sekandung bahkan semenda serta anak angkat yang telah menjadi tanggungan sepenuhnya, diberikan tambahan PTKP senilai Rp 4.500.000 untuk setiap anggota keluarga, dengan jumlah maksimal tiga orang.

\section{Penerimaan Pajak}

Menurut Undang-Undang No. 15 Tahun 2017 tentang Anggaran Pendapatan dan Belanja Negara Tahun Anggaran 2018, penerimaan pajak ialah seluruh penerimaan yang terdiri dari Pendapatan Pajak Dalam Negeri dan Pendapatan Pajak Perdagangan Internasional. Seluruh penerimaan negara yang berasal dari pendapatan pajak penghasilan, pendapatan pajak pertambahan nilai barang maupun jasa, dan pajak penjualan atas barang mewah, pendapatan pajak bumi dan bangunan, pendapatan cukai, dan pendapatan pajak lainnya disebut dengan Pendapatan Pajak Dalam Negeri. Sedangkan Pendapatan Pajak Perdagangan Internasional merupakan seluruh penerimaan negara yang bersumber dari pendapatan bea masuk dan bea keluar.

\section{METODE PENELITIAN}

Berdasarkan permasalahan yang diteliti, maka jenis penelitian ini adalah penelitian deskriptif kualitatif. Sukmadinata (2011 : 73) menuturkan bahwa penelitian deskriptif kualitatif bertujuan untuk menguraikan serta melukiskan fenomena yang tampak, baik berupa alamiah ataupun rekayasa manusia dengan lebih memonitor kualitas, karateristik, serta ketergantungan antar kegiatan. Penggunaan metode kualitatif dalam penelitian bermaksud untuk mengantongi data yang lengkap dan lebih mengakar serta bersifat kredibel sehingga pada akhirnya tujuan akhir dari investigasi ini dapat diraih (Sugiyono, dalam Dewi, 2013). Fokus penelitian dalam penelitian ini adalah Penghasilan Tidak Kena Pajak (PTKP), penerimaan pajak dan tingkat pertumbuhan Wajib Pajak. Pengumpulan data dilakukan melalui wawancara langsung dengan pihak KPP Pratama Sidoarjo Barat dan studi dokumentasi. Subjek penelitian dalam penelitian ini adalah Kepala Seksi Pemeriksaan dan Kepala Seksi Pengawasan dan Konsultasi 3 KPP Pratama Sidoarjo Barat. Data yang diperoleh berupa data primer dan data sekunder. Teknik analisis data yang dipergunakan adalah teknik analisis data Miles dan Huberman, dimana dalam teknik tersebut terdapat 
empat tahapan yaitu pengumpulan data, reduksi data, penyajian data dan penarikan kesimpulan.

\section{HASIL PENELITIAN DAN PEMBAHASAN \\ Penetapan Peraturan Menteri Keuangan No. 101/PMK.010/2016 Tentang Penyesuaian Besarnya Penghasilan Tidak Kena Pajak}

Setiap kebijakan yang berlaku di Indonesia tentu telah melalui berbagai proses kajian dan telah di analisa secara mendalam sebelum akhirnya diputuskan untuk di jalankan. Sama hal nya dengan penetapan kebijakan PMK No. 101/PMK.010/2016 Tentang Penyesuaian Besarnya Penghasilan Tidak Kena Pajak. Pemerintah tentu mempertimbangkan dengan matang tujuan ditetapkannya peraturan ini hingga dampak yang nantinya akan dirasakan oleh pemerintah hingga masyarakat itu sendiri. Peraturan ini sendiri sebenarnya bertujuan untuk meningkatkan daya beli masyarakat yang artinya akan mendorong masyarakat agar lebih bersifat konsumtif.

Kebijakan mengenai Penghasilan Tidak Kena Pajak (PTKP) ini sebenarnya bukanlah hal yang baru. Mengingat perubahan kebijakan mengenai PTKP ini sebenarnya telah berubah sebanyak sepuluh kali dalam kurun waktu lebih dari 30 tahun. Namun apabila dilihat secara mendetail, turunnya PTKP ini akan merugikan di sisi aparatur pajak. Hal ini karena dengan meningkatnya besaran PTKP ini, base line akan jauh lebih rendah. Hal ini disebabkan karena pajak yang disetorkan oleh Wajib Pajak, jumlahnya akan jauh lebih sedikit dibandingkan sebelumya. Sehingga mau tidak mau, aparatur pajak harus lebih "giat" agar penerimaan pajak tetap meningkat.

Hal berbeda akan berdampak pada Wajib Pajak. Salah satu tujuan dari penerapan PMK No. 101/PMK.010/2016 Tentang Penyesuaian Besarnya Penghasilan Tidak Kena Pajak adalah untuk memberikan keadilan dalam perpajakan. Adolf Wagner mengemukakan bahwa asas keadilan ialah dalam kondisi yang sama, antara Wajib Pajak yang satu dengan Wajib Pajak yang lainnya harus dikenakan pajak dalam jumlah yang sama tanpa membeda-bedakan (Jeta, 2017, http://www.pajaker.com /2017/05/14-asas-pemungutan-pajak-menurut-ahli.html, 2 Agustus 2018). Adam Smith juga mengemukakan hal serupa, yaitu pemerintah harus memperhatikan adanya kesesuaian dan keseimbangan antara kemampuan Wajib Pajak dan jumlah yang harus dibayarkan. Oleh karena itu, dengan adanya penyesuaian PTKP ini diharapkan mampu memenuhi asas keadilan. Sri Mulyani, Menteri Keuangan pernah menyampaikan bahwa keadilan dalam pemungutan pajak adalah dengan menerapkan PTKP dan mengoptimalkan pemungutan pajak pada kelompok yang mampu (Wicaksono, 2017, http://m.liputan6.com/amp/2935030/sri-mulyani-pungutan-pajak-harus-berasas-keadilan, 2 Agustus 2018). Hal itu menunjukkan bahwa dengan PTKP memberikan kesempatan yang sama pada Wajib Pajak. Wajib Pajak tentu diuntungkan karena dengan peningkatan PTKP ini jumlah pajak yang dikenakan jumlahnya akan jauh lebih sedikit bahkan untuk yang berpenghasilan dibawah PTKP tidak dikenakan pajak.

Selain itu, dengan penyesuaian PTKP ini tentu akan berdampak pada perekonomian Indonesia secara makro. Dengan banyaknya penghasilan yang ada di tangan masyarakat tentu akan mendorong masyarakat untuk bersikap lebih konsumtif. Itu artinya akan ada banyak barang terjual, sehingga otomatis akan meningkatkan perekonomian masyarakat. Hal ini menunjukkan bahwa PTKP menjadi salah satu instrument kebijakan fiskal yang berfungsi sebagai regulator. Disini PTKP akan menjadi sebuah instrumen untuk mengatur serta menyelenggarakan kebijakan pada sektor sosial dan ekonomi.

Selain itu, PTKP ini sebenarnya identik dengan standart minimal hidup masyarakat atau yang biasa disebut dengan minimum standar of living. PTKP menjadi penghasilan dengan batas tertentu yang tidak dikenakan pemotongan pajak karena nantinya akan digunakan oleh 
Wajib Pajak demi memenuhi kebutuhan pokoknya, untuk memperoleh penghasilan yang akan menjadi objek pajak (Heriani, 2017, http://m.hukumonline.com /berita/baca/lt5970aca3425a/penerapan-ptkp-sesuai-umr-dan-paradigma-penerimaan pajak, 1 Agustus 2018). PTKP ini merupakan pengurang atas penghasilan netto yang selanjutnya akan dikalikan dengan besaran tarif $\mathrm{PPh}$ yang akan menunjukkan berapa jumlah pajak yang dibayar. Itu artinya PTKP ini menunjukkan penghasilan yang terbebas dari pajak dan dapat digunakan masyarakat untuk kehidupannya.

Kembali di tahun 2016, ada berbagai strategi yang dilakukan KPP Pratama Sidoarjo Barat untuk memperkenalkan Peraturan Menteri Keuangan No. 101/PMK.010/2016. Strategi yang dijalankan memang secara umum sama dengan KPP Pratama lain di seluruh Indonesia. Yang pertama adalah melalui sosialisasi yang rutin dilaksanakan oleh KPP Pratama Sidoarjo Barat. Penyebaran informasi mengenai perubahan PTKP ini juga disebarkan melalui media sosial dimana memang saat ini media sosial menjadi sarana komunikasi yang lebih cepat. Selain itu, KPP Pratama Sidoarjo Barat juga aktif dalam berkomunikasi secara langsung dengan Wajib Pajak. Salah satunya adalah melalui konseling yang terbuka untuk seluruh Wajib Pajak.

Berbagai tanggapan tentu diterima KPP Pratama Sidoarjo Barat setelah diterapkannya Peraturan Menteri Keuangan No. 101/PMK.010/2016 tentang Penyesuaian Besarnya Penghasilan Tidak Kena Pajak ini. Namun secara umum memang masyarakat sangat senang menanggapi kenaikan PTKP ini. Hal tersebut karena masyarakat dengan penghasilan dibawah Rp 4.500.000 telah terbebas dari pajak, sehingga penghasilan mereka dapat digunakan untuk memenuhi kebutuhan pokoknya. Dan untuk masyarakat dengan penghasilan di atas PTKP tentu pengenaan pajaknya akan semakin kecil. Dari pejabaran di atas, terlihat jelas bahwa memang dengan ditetapkannya Peraturan Menteri Keuangan No. 101/PMK.010/2016 dalam hal peningkatan PTKP memang semata-mata adalah untuk kesejahteraan masyarakat. Perubahan PTKP menjadi $\mathrm{Rp} 4.500 .000$ sebulan atau Rp 54.000.000 setahun diharapkan mampu diimbangi dengan peningkatan konsumsi masyarakat. Sehingga dengan begitu perekonomian di Indonesia juga akan semakin membaik. Begitu pula dengan keadilan yang diharapkan telah dirasakan oleh seluruh komponen masyarakat. Oleh karena itu, hendaknya perubahan PTKP ini mampu disikapi dengan baik oleh Wajib Pajak.

\section{Analisis Tingkat Pertumbuhan Wajib Pajak Setelah Ditetapkannya PMK No.} 101/PMK.010/2016 Tentang Penyesuaian Besarnya Penghasilan Tidak Kena Pajak

Hampir seluruh KPP Pratama di Indonesia tentu berharap tingkat pertumbuhan Wajib Pajak meningkat setiap tahunnya. Tingkat pertumbuhan ini nantinya juga akan memberikan pengaruh yang cukup signifikan pada jumlah penerimaan yang nantinya akan diperoleh. Begitu pula dengan KPP Pratama Sidoarjo Barat yang memiliki berbagai strategi untuk mampu menarik perhatian Wajib Pajak baru.

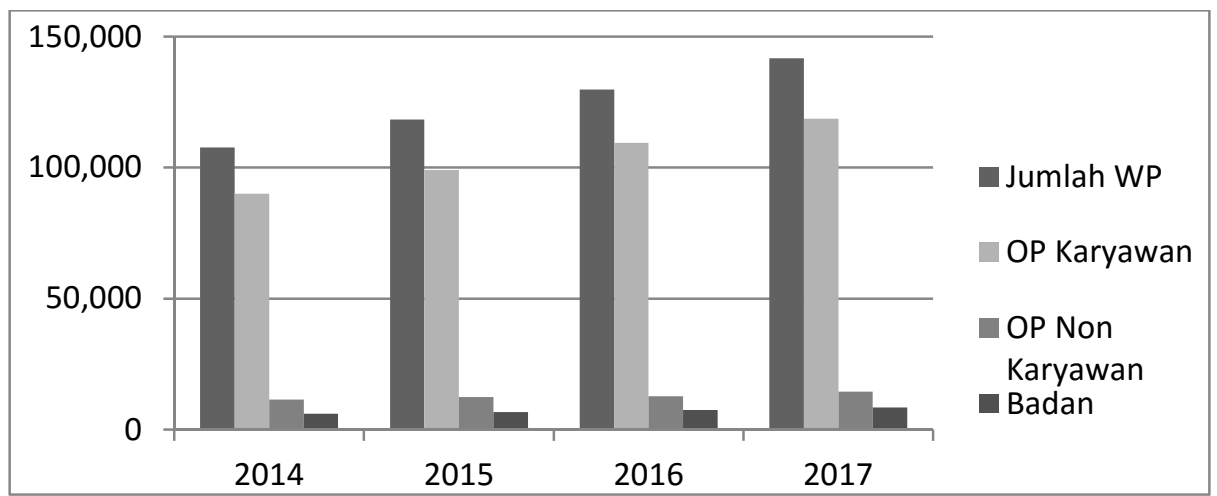

Gambar 1. Statistik Tingkat Pertumbuhan Wajib Pajak

JAD: Jurnal Riset Akuntansi dan Keuangan Dewantara

Vol. 1 No. 2, Desember 2018

https://ejournal.stiedewantara.ac.id/index.php/JAD/issue/view 


\section{KPP Pratama Sidoarjo Barat}

(Sumber : KPP Pratama Sidoarjo Barat, 2018, telah diolah)

Dari statistik di atas menunjukkan bahwa pertumbuhan Wajib Pajak pada KPP Pratama Sidoarjo Barat terus mengalami kenaikan. Kenaikan yang paling signifikan terlihat pada OP Karyawan. OP Karyawan terlihat meningkat drastis dibanding dengan OP Non Karyawan maupun Badan. Peningkatan OP Karyawan ini merupakan dampak dari perluasan sosialisasi yang telah dilakukan oleh KPP Pratama Sidoarjo Barat. Perluasan sosialisasi ini memang dilakukan KPP Pratama Sidoarjo Barat untuk menggaet Wajib Pajak baru yang berstatus karyawan.

Perlu diingat bahwa Penghasilan Tidak Kena Pajak berpengaruh pada penghasilan Wajib Pajak Orang Pribadi. Dalam UU No. 7 tahun 1983 yang terakhir kali diubah menjadi UU No.36 Tahun 2008 tentang Pajak Penghasilan, disebutkan bahwa Kepada orang pribadi atau perseorangan sebagai Wajib Pajak dalam negeri diberikan pengurangan berupa Penghasilan Tidak Kena Pajak. Oleh karena itu, yang paling berdampak tentu adalah karyawan yang bekerja dalam perusahaan. Dalam gambar 1 memperlihatkan bahwa terjadi peningkatan pada OP Karyawan, hal ini bisa saja dikarenakan adanya karyawan-karyawan yang muncul sebagai Wajib Pajak baru yang diimbangi oleh munculnya Wajib Pajak Badan yang baru. Pada gambar 1 juga terlihat bahwa terdapat peningkatan pada Wajib Pajak Badan. Hal ini menunjukkan bahwa ada banyak badan-badan baru yang mendaftar sebagai Wajib Pajak, yang otomatis melahirkan Wajib Pajak baru.

Namun, meskipun yang paling terpengaruh atas perubahan PTKP tersebut adalah Wajib Pajak karyawan, hal tersebut tidak serta merta dapat meningkatkan pertumbuhan Wajib Pajak. Meskipun memang dengan meningkatnya PTKP konsumsi dan daya beli masyarakat meningkat, namun hal tersebut memberi pengaruh yang sangat kecil bagi masyarakat untuk mendaftarkan diri sebagai Wajib Pajak. Ada beberapa motivasi Wajib Pajak untuk mendaftarkan diri sebagai Wajib Pajak yaitu :

1. Untuk persyaratan administrasi

Saat ini, hampir seluruh administrasi di perusahan mengharuskan untuk menyertakan

NPWP. Seperti pengurusan administrasi ijin pendirian usaha, pengurusan administrasi untuk pinjaman, hampir semuanya mengharuskan untuk menyertakan NPWP.

2. Pemotongan pajak yang lebih rendah

Sesuai dengan UU No. 36 tahun 2008 Pasal 21 ayat 5a menjelaskan bahwa Wajib Pajak orang pribadi yang tidak mempunyai NPWP tapi memperoleh penghasilan, akan dikenakan pemotongan PPh 21 dengan tarif lebih tinggi 20\% dibanding Wajib Pajak yang memiliki NPWP.

Hal itu menunjukkan bahwa, secara umum, tingkat pertumbuhan Wajib Pajak memang meningkat, namun pengaruhnya sangat kecil apabila hal tersebut dihubungkan dengan perubahan besaran PTKP. Perubahan PTKP ini apabila dihubungkan dengan pertumbuhan Wajib Pajak hanya terbatas pada, PTKP merubah batasan seseorang untuk mendaftar menjadi Wajib Pajak, karena Wajib Pajak dengan penghasilan di bawah PTKP ini tidak wajib memiliki NPWP sesuai dengan PMK No.243/PMK.03/2014 tentang Surat Pemberitahuan.

Bukan hanya terhadap pertumbuhan Wajib Pajak, peningkatan PTKP yang berpengaruh pada konsumsi dan daya beli masyarakat dan mempengaruhi kondisi ekonomi Wajib Pajak nyatanya belum diimbangi kesadaran masyarakat dalam membayar maupun melaporkan pajaknya. Memang, dengan diterapkannya PMK No. 101/PMK.010/2016, jumlah pajak yang dibayarkan oleh Wajib Pajak jumlahnya akan jauh lebih sedikit. Namun meskipun jumlah yang Wajib Pajak bayarkan jumlahnya lebih sedikit, belum tentu membuat Wajib Pajak sadar akan pajak. Kesadaran masyarakat memang meningkat setiap tahunnya, namun bukan karena 
adanya peningkatan PTKP. Kesadaran serta kepatuhan masyarakat akan pajak ini lebih banyak melihat dari sisi penggunaan pajak tersebut. Untuk apa pajak tersebut digunakan, realisasi penggunaan tersebut dan manfaat yang bisa dirasakan oleh masyarakat secara langsung yang mampu mempengaruhi kesadaran akan pajak. Keadilan pajak juga memberikan pengaruh yang cukup besar pada kesadaran akan pajak. Asas keadilan pajak menyatakan bahwa pajak itu harus adil dan merata. Pajak yang dikenakan pada orang pribadi harus sebanding dengan kemampuanya untuk membayar pajak tersebut dan sesuai dengan manfaat yang diterimanya dari negara (Wijiraharjo, 2008, https://wijiraharjo.wordpress.com/2008/02/02/asas-asas-pemungutan-pajak, 1 Agustus 2018). Oleh karena itu, ketika masyarakat merasa apa yang mereka keluarkan untuk membayar pajak telah sesuai dengan manfaat yang telah mereka rasakan, tentunya nantinya akan menumbuhkan kesadaran akan membayar pajak. Pemaparan di atas mendukung penelitian Berutu dan Harto (2012) bahwa dimensi persepsi keadilan pajak dipengaruhi oleh kepentingan pribadi (Self-Interest) yang merupakan suatu dorongan atau motivasi lain dari dalam diri WP OP yang berhubungan langsung dengan persepsi yang akan mempegaruhi tingkat kepatuhan pajak mereka, atau dengan kata lain adil atau tidaknya sistem perpajakan yang berlaku akan mempengaruhi tingkat kepatuhan pajak WP OP.

Tabel 2. Persentase Realisasi Penyampaian SPT Wajib Pajak Orang Pribadi

Tahun 2014-2017

\begin{tabular}{ccccc}
\hline Tahun & Jumlah WPOP & Realisasi SPT & Persentase & Pertumbuhan \\
\hline 2014 & 101.643 & 43.990 & $43,3 \%$ & - \\
2015 & 111.690 & 47.654 & $42,7 \%$ & $8,3 \%$ \\
2016 & 122.324 & 51.291 & $41,9 \%$ & $7,6 \%$ \\
2017 & 133.180 & 53.248 & $40 \%$ & $3,8 \%$ \\
\hline
\end{tabular}

Sumber : KPP Pratama Sidoarjo Barat, 2018, telah diolah

Dalam tabel 2 di atas menunjukkan bahwa terdapat selisih antara jumlah Wajib Pajak dengan realisasi penyampaian SPT. Hal ini bisa saja dipengaruhi oleh PMK No.243/PMK.03/2014 tentang Surat Pemberitahuan Pajak yang menyatakan bahwa Wajib Pajak Orang Pribadi yang berpenghasilan tidak lebih dari besaran PTKP dikecualikan atau tidak diwajibkan untuk menyampaikan SPT Tahunan. Hal ini menunjukkan bahwa dengan meningkatnya PTKP memungkinkan bahwa Wajib Pajak yang sebelumnya memperoleh gaji di atas PTKP, sekarang berada di bawah PTKP, dengan begitu Wajib Pajak tersebut tidak perlu lagi melaporkan SPT, yang tentunya akan mempengaruhi jumlah realisasi penyampaian SPT KPP Pratama Sidoarjo Barat. Namun, hal tersebut diimbangi dengan munculnya Wajib Pajak sehingga proyeksi realisasi penyampaian SPT KPP Pratama Sidoarjo Barat tetap meningkat.

Ada beberapa hal yang mampu meningkatkan kepatuhan Wajib Pajak, yang pertama adalah melalui sosialisasi perpajakan. Sosialisasi perpajakan ini merupakan suatu upaya Direktorat Jenderal Pajak yang dilakukan melalui Kantor Pelayanan Pajak untuk memberikan suatu pengertian, pemahaman informasi serta pembinaan kepada masyarakat mengenai perpajakan. Yang kedua adalah melalui pemeriksaan perpajakan. Pemeriksaan pajak ini lebih diintensifkan pada Wajib Pajak yang tingkat kepatuhan pajaknya rendah dan perlu adaya pengawasan penuh.

Dengan meningkatnya pertumbuhan Wajib Pajak serta semakin tingginya kesadaran Wajib Pajak maka akan memicu peningkatan penerimaan pajak. Pernyataan tersebut didukung oleh penelitian Nafia dan Sunandar (2016) yang menunjukkan bahwa dengan meningkatnya pertumbuhan Wajib Pajak Orang Pribadi, memicu untuk meningkatan penerimaan pajak penghasilan pada KPP Pratama Tegal dimana pertumbuhan rata-rata Wajib Pajak Orang Pribadi sebesar 12,95\%. 


\section{Analisis Penerimaan Pajak Penghasilan KPP Pratama Sidoarjo Barat Setelah Ditetapkannya PMK No. 101/PMK.010/2016 Tentang Penyesuaian Besarnya Penghasilan Tidak Kena Pajak}

Penerimaan pajak pada KPP Pratama Sidoarjo Barat terus mengalami peningkatan setelah ditetapkannya PMK No. 101/PMK.010/2016 Tentang Penyesuaian Besarnya Penghasilan Tidak Kena Pajak. Penerimaan pajak yang paling berpengaruh setelah adanya penyesuaian besarnya PTKP adalah penerimaan PPh pasal 21. Hal tersebut karena dalam PPh pasal 21, PTKP merupakan pengurang atas penghasilan netto yang nantinya dihasilkan Penghasilan Kena Pajak (PKP) yang menjadi dasar pengenaan pajak. Dengan berkurangnya PKP otomatis pajak yang dibayarkan oleh Wajib Pajak jumlahnya akan mempengaruhi penerimaan $\mathrm{PPh}$ pasal 21.

Tabel 3. Pertumbuhan Penerimaan PPh Pasal 21

\begin{tabular}{ccc}
\hline Tahun & Penerimaan PPh Pasal 21 & Pertumbuhan \\
\hline 2014 & 22.015 .371 .529 & - \\
2015 & 28.019 .941 .288 & $27,3 \%$ \\
2016 & 35.347 .168 .683 & $26,2 \%$ \\
2017 & 42.795 .933 .760 & $21,1 \%$ \\
\hline
\end{tabular}

Sumber : KPP Pratama Sidoarjo Barat, 2018, telah diolah

Dari tabel 3 di atas menunjukkan bahwa penerimaan PPh pasal 21 pada KPP Pratama Sidoarjo Barat terus mengalami peningkatan setiap tahunnya setelah ditetapkannya PMK No. 101/PMK.010/2016 Tentang Penyesuaian Besarnya Penghasilan Tidak Kena Pajak. Namun, secara logika seharusnya peningkatan PTKP ini menurunkan penerimaan PPh pasal 21. Hal ini karena dengan meningkatnya PTKP, jumlah pajak yang dibayarkan Wajib Pajak orang per orang akan lebih sedikit, sehingga jumlah penerimaan PPh pasal 21 seharusnya menurun.

Tabel 4. Simulasi PPH Pasal 21

\begin{tabular}{|c|c|c|c|c|c|}
\hline \multirow[t]{2}{*}{ Keterangan } & \multicolumn{5}{|c|}{ WP K/0 } \\
\hline & & KP 2015 & & KP 2016 & Perubahan \\
\hline Gaji & $\mathrm{Rp}$ & 5.750 .000 & $\mathrm{Rp}$ & 5.750 .000 & - \\
\hline Biaya Jabatan & $\mathrm{Rp}$ & 287.500 & $\mathrm{Rp}$ & 287.500 & - \\
\hline Iuran Pensiun & $\mathrm{Rp}$ & 200.000 & $\mathrm{Rp}$ & 200.000 & - \\
\hline Penghasilan netto satu & $\mathrm{Rp}$ & 5.262 .500 & $\mathrm{Rp}$ & 5.262 .500 & - \\
\hline Peghasilan netto satu & $\mathrm{Rp}$ & 63.150 .000 & $\mathrm{Rp}$ & 63.150 .000 & - \\
\hline PTKP & $\mathrm{Rp}$ & 39.000 .000 & $\mathrm{Rp}$ & 58.500 .000 & -19.500 .000 \\
\hline PKP & $\mathrm{Rp}$ & 24.150 .000 & $\mathrm{Rp}$ & 4.650 .000 & -19.500 .000 \\
\hline $\mathrm{PPh}$ Pasal 21 satu tahun & $\mathrm{Rp}$ & 1.207 .500 & $\mathrm{Rp}$ & 232.500 & -975.000 \\
\hline PPh Pasal 21 satu bulan & $\mathrm{Rp}$ & 100.625 & $\mathrm{Rp}$ & 19.375 & -81.250 \\
\hline
\end{tabular}

Sumber : PER-16/PJ/2016, 2016

Dari tabel 4 di atas menunjukkan bahwa perubahan PTKP tidak memberikan pengaruh yang cukup besar pada PPh Pasal 21 dan membuktikan bahwa seharusnya dengan adanya perubahan PTKP penerimaan PPh pasal 21 menurun karena jumlah yang dibayarkan Wajib Pajak jumlahnya menurun dibanding PTKP sebelumnya. Hal ini menunjukkan bahwa ada faktor lain diluar kebijakan peningkatan PTKP yang mampu meningkatkan penerimaan $\mathrm{PPh}$ pasal 21. Faktor pertama adalah meningkatnya jumlah Wajib Pajak Orang Pribadi. Gambar 1 telah menggambarkan bahwa jumlah Wajib Pajak karyawan mengalami peningkatan yang cukup tinggi. Dengan meningkatnya jumlah Wajib Pajak Karyawan tersebut otomatis memunculkan PPh terutang yang baru yang mampu menopang penurunan yang seharusnya terjadi. Dengan begitu, penerimaan PPh pasal 21 akan tetap meningkat seiring dengan JAD: Jurnal Riset Akuntansi dan Keuangan Dewantara Vol. 1 No. 2, Desember 2018

https://ejournal.stiedewantara.ac.id/index.php/JAD/issue/view 
meningkatnya jumlah Wajib Pajak. Pemaparan tersebut mendukung penelitian Nafia dan Sunandar (2016) yang menujukkan bahwa penerimaan Pajak Penghasilan yang diterima KPP Pratama Tegal pada tahun 2011 yaitu sebesar Rp 30.121.460.981 dan pada tahun 2012 sebesar Rp 39.458.757.629, salah satu faktor yang mengakibatkan kenaikan penerimaan Pajak Penghasilan adalah semakin meningkatnya jumlah Wajib Pajak setiap tahunnya.

Faktor kedua adalah meningkatnya UMR (Upah Minimum Regional). UMR sebenarnya merupakan salah satu bagian pertimbangan pemerintah dalam menetapkan kebijakan mengenai PTKP. PTKP ditetapkan berdasarkan kemampuan masyarakat dalam membayar pajak dari berbagai tingkatan masyarakat. Dengan meningkatnya UMR batas pertimbangan pengusaha dalam menentukan upah bagi karyawannya juga otomatis meningkat. Sehingga apabila dihubungkan dengan peningkatan jumlah Wajib Pajak yang telah disebutkan dalam sub bab sebelumnya, menunjukkan bahwa munculnya Wajib Pajak baru dengan penghasilan di atas PTKP. Sehigga otomatis jumlah penghasilan setelah dikurangi dengan PTKP jumlahnya akan meningkat dan akan meningkatkan jumlah PPh terutang, sehingga pajak yang dibayarkan oleh Wajib Pajak jumlahnya juga akan meningkat yang kemudian akan meningkatkan jumlah penerimaan PPh pasal 21. Dari kedua faktor di atas, menunjukkan bahwa peningkatan penerimaan $\mathrm{PPh}$ pasal 21 dipengaruhi oleh berbagai faktor. Sehingga dapat terlihat bahwa peningkatan PTKP ini memang mampu memberikan pengaruh pada penerimaan $\mathrm{PPh}$ pasal 21 namun xpengaruhnya kecil sehingga diperlukan penopang lain agar penerimaan pajak tetap meningkat.

Perubahan PTKP tidak memberikan pengaruh yang signifikan pada penerimaan pajak secara keseluruhan. Hal ini disebabkan karena memang penerimaan KPP Pratama Sidoarjo Barat yang paling besar tidak ditopang oleh penerimaan PPh pasal 21, namun ditopang oleh Pajak Pertambahan Nilai (PPN) dan PPh Final. Perlu diingat bahwa pemerintah memiliki berbagai system pemungutan pajak. Salah satunya adalah withholding tax system. Dan system ini merupakan system yang paling berpengaruh pada penerimaan pajak KPP Pratama Sidoarjo Barat. PPh Final pasal 4 ayat (2) dilakukan oleh pihak pemberi peghasilan sehubungan dengan pembayaran untuk objek tertentu, seperti sewa tanah dan/atau bangunan, jasa kontruksi, pengalihan hak atas tanah dan/atau bangunan lainnya. (Anonimous, 2012, http://pajak.go.id/content/kenali-para-pemotong-dan-pemungut-pajak-di-Indonesia, 5 Agustus 2018)

Kebijakan perubahan PTKP ini memang bermaksud untuk meningkatkan konsumsi masyarakat. Dengan begitu, masyarakat akan lebih banyak menggunakan penghasilannya untuk membeli barang sehingga akhirnya pajak akan meningkat. Hal ini juga menjawab bagaimana pengaruh parubahan PTKP terhadap penerimaan PPN dan PPnBM. Namun, meskipun pembelian barang-barang tertentu mampu meningkatkan PPN, peningkatan PTKP belum bisa secara maksimal dapat meningkatkan penerimaan PPN dan PPnBM. Hal ini dikarenakan dengan perubahan PTKP ini cenderung mendorong masyarakat untuk memenuhi kebutuhan pokoknya terlebih dahulu, sedangkan barang-barang kebutuhan ini masuk ke dalam kategori bebas PPN. Dalam Peraturan Menteri Keuangan No.116/PMK.010/2017 dalam pasal 1 menyebutkan bahwa jenis barang yang tidak dikenai Pajak Pertambahan Nilai adalah barang tertentu dalam kelompok barang antara lain barang kebutuhan pokok yang sangat dibutuhkan oleh rakyat banyak. Adapun barang kebutuhan pokok tersebut seperti :
a. Beras
g. Telur
b. Jagung
h. Susu
c. Sagu
i. Buah-buahan
d. Kedelai
j. Sayur-sayuran
e. Garam konsumsi
k. Ubi-ubian
f. Daging
1. Bumbu-bumbuan, dan

JAD: Jurnal Riset Akuntansi dan Keuangan Dewantara

Vol. 1 No. 2, Desember 2018

https://ejournal.stiedewantara.ac.id/index.php/JAD/issue/view 


\section{m. Gula konsumsi}

Jadi sebenarnya perubahan PTKP ini lebih kepada untuk mendorong masyarakat agar bisa memperbaiki kehidupannya. Penerimaan PPN memang bisa ditingkatkan melalui perubahan PTKP ini, namun pengaruhya sangat kecil sekali. Begitu pula dengan pengenaan PPnBM, peningkatan PTKP dari yang sebelumnya sebesar Rp 3.000 .000 menjadi Rp 4.500.000 sepertinya tidak memberikan pengaruh pada pembelian barang-barang mewah. Kecuali bagi Wajib Pajak yang memiliki penghasilan yang tinggi. Pemaparan di atas mendukung penelitian Nuritomo (2008) bahwa peningkatan PTKP belum mampu meningkatkan belanja masyarakat dengan meningkatkan PPN dan PPnBM, hal ini diakibatkan oleh perubahan PTKP yang secara umum hanya dirasakan oleh wajib pajak kecil. Wajib pajak kecil memiliki kecenderungan belanja yang hampir serupa karena penghasilan yang didapatkan kecil sehingga kemampuan untuk meningkatkan penerimaan pajak ini sangat kecil.

Seluruh pemaparan di atas menunjukkan bahwa Peraturan Menteri Keuangan No. 101/PMK.010/2016 Tentang Penyesuaian Besarnya Penghasilan Tidak Kena Pajak memang telah berlaku selama dua tahun terakhir namun akan sangat sulit apabila melihat apakah dengan peraturan ini telah mampu mendongkrak penerimaan pajak terutama apabila hanya dilihat dari satu sisi saja sedangkan pengaruhnya akan saling terhubung satu sama lain. Oleh karena itu, KPP Pratama Sidoarjo Barat perlu melakukan upaya-upaya lain untuk meningkatkan penerimaan pajak diluar adanya kebijakan mengenai peningkatan PTKP ini. Ada lima upaya yang ditempuh KPP Pratama Sidoarjo Barat untuk meningkatkan penerimaan pajak, yaitu :

1. Sosialisasi

2. Meningkatkan pengawasan

3. Melakukan pemeriksaan

4. Konseling/ konsultasi

5. Penagihan

\section{E. PENUTUP}

Berdasarkan pembahasan yang telah diuraikan maka dapat disimpulkan bahwa salah satu tujuan dari penerapan PMK No. 101/PMK.010/2016 Tentang Penyesuaian Besarnya Penghasilan Tidak Kena Pajak adalah untuk meningkatkan daya beli masyarakat sehingga akan mendorong masyarakat untuk bersikap lebih konsumtif. Dengan begitu banyak barang akan terjual, sehingga secara otomatis akan meningkatkan perekonomian masyarakat. Selain itu, tujuan dari penerapan PMK No. 101/PMK.010/2016 Tentang Penyesuaian Besarnya Penghasilan Tidak Kena Pajak adalah untuk memberikan keadilan dalam perpajakan. PTKP memberikan kesempatan yang sama pada Wajib Pajak karena dengan peningkatan PTKP ini jumlah pajak yang dikenakan jumlahnya akan jauh lebih sedikit bagi Wajib Pajak yang berpenghasilan di atas PTKP, dan untuk yang berpenghasilan dibawah PTKP tidak dikenakan pajak.

Tingkat pertumbuhan Wajib Pajak Setelah Ditetapkannya PMK No. 101/PMK.010/2016 Tentang Penyesuaian Besarnya Penghasilan Tidak Kena Pajak terus mengalami peningkatan selama dua tahun terakhir. Namun, pertumbuhan jumlah Wajib Pajak ini bukanlah berasal dari perubahan PTKP. Ada beberapa faktor lain yang mampu meningkatkan jumlah Wajib Pajak. Munculnya Wajib Pajak baru diimbangi dengan peningkatan jumlah Wajib Pajak Badan. Kebutuhan Wajib Pajak akan persyaratan administrasi dan pemotongan pajak yang lebih rendah bagi Wajib Pajak ber NPWP memberikan motivasi Wajib Pajak untuk mendaftarkan diri sebagai Wajib Pajak. Bukan hanya terhadap pertumbuhan Wajib Pajak, peningkatan PTKP belum memberikan pengaruh 
pada kesadaran masyarakat dalam membayar maupun melaporkan pajaknya. Penggunaan pajak dan keadilan pajak lebih mempengaruhi kesadaran serta kepatuhan masyarakat. Dan ada beberapa strategi yang dilakukan KPP Pratama Sidoarjo Barat untuk meningkatkan kepatuhan Wajib Pajak yaitu melalui sosialisasi perpajakan, pemeriksaan perpajakan, dan pemeriksaan pajak.

Penerimaan Pajak Penghasilan KPP Pratama Sidoarjo Barat Setelah Ditetapkannya PMK No. 101/PMK.010/2016 Tentang Penyesuaian Besarnya Penghasilan Tidak Kena Pajak mengalami kenaikan yang cukup signifikan begitu pula pada penerimaan $\mathrm{PPh}$ pasal 21 . $\mathrm{PPh}$ pasal 21 terus meningkat setiap tahunnya, padahal secara logika seharusnya peningkatan PTKP ini menurunkan penerimaan $\mathrm{PPh}$ pasal 21. Hal ini disebabkan ada faktor lain diluar kebijakan peningkatan PTKP yang mampu meningkatkan penerimaan PPh pasal 21 di KPP Pratama Sidoarjo Barat yaitu meningkatnya jumlah Wajib Pajak Orang Pribadi meningkatnya UMR (Upah Minimum Regional). Perubahan PTKP memberikan pengaruh yang kecil pada penerimaan pajak secara keseluruhan, karena penerimaan KPP Pratama Sidoarjo Barat yang paling besar ditopang oleh Pajak Pertambahan Nilai (PPN) dan PPh Final. Namun, meskipun pembelian barang-barang tertentu mampu meningkatkan PPN, peningkatan PTKP belum bisa secara maksimal dapat meningkatkan penerimaan PPN dan PPnBM. dikarenakan dengan perubahan PTKP ini cenderung mendorong masyarakat untuk memenuhi kebutuhan pokoknya terlebih dahulu, sedangkan barang-barang kebutuhan ini masuk ke dalam kategori bebas PPN. Oleh karena itu, pengaruh pada PPnBM juga sangat rendah karena Wajib Pajak lebih banyak menggunakan penghasilannya untuk memenuhi kebutuhan pokoknya dibanding membeli barang-barang mewah. Sehingga, KPP Pratama Sidoarjo Barat perlu melakukan upaya-upaya lain untuk meningkatkan penerimaan pajak diluar adanya kebijakan mengenai peningkatan PTKP, yaitu melalui sosialisasi pajak, meningkatkan pengawasan, melakukan pemeriksaan, konseling/ konsultasi serta penagihan.

Untuk KPP Pratama Sidoarjo Barat diharapkan dapat terus meningkatkan jumlah Wajib Pajak khususnya Wajib Pajak Orang Pribadi. Pendekatan dan kerjasama perlu dilakukan mengingat KPP Pratama Sidoarjo Barat mencakup wilayah-wilayah dengan banyak perusahaan besar sehingga potensi Wajib Pajak baru dapat dikembangkan. Dan kepada peneliti selanjutnya diharapkan mampu menggali lebih dalam lagi mengenai tingkat pertumbuhan Wajib Pajak dan penerimaan pajak setelah adanya penyesuaian besarnya PTKP dengan memperluas lokasi penelitian sehingga hasil yang diperoleh mampu memperlihatkan secara lebih gamblang pengaruh dari adanya penyesuaian PTKP.

\section{DAFTAR PUSTAKA}

Anonimous. 2012. Kenali Para Pemotong Dan Pemungut Pajak Di Indonesia. Tersedia : http://pajak.go.id/content/kenali-para-pemotong-dan-pemungut-paj ak-di-Indonesia. [ 5 Agustus 2018]

Ariyanti, Fiki. 2016. Alasan Gaji Rp 4,5 Juta Per Bulan Bebas Pajak. [Online]. Tersedia : Fiki Ariyanti, 2016, http://m.liputan6.com/amp/2477210/alasan-gaji-rp-45-juta-per-bulanbebas-pajak.html. [5 Januari 2018]

Berutu, Dian Anggraeni dan Puji Harto. 2012. Persepsi Keadilan Terhadap Perilaku Kepatuhan Wajib Pajak Orag Pribadi (WPOP). Diponegoro Journal of Accounting, 2, $1-10$

Iqbal, Muhammad. 2015. Pajak Sebagai Ujung Tombak Pembangunan. [Online]. Tersedia : http://www.pajak.go.id/content/article.pajak-sebagai-ujun-tombak-pembangunan.html. [15 Januari 2018] 
Jeta, David. 2017. 14 Asas Pemungutan Pajak Menurut Para Ahli Terlengkap. Tersedia: http://www.pajaker.com/2017/05/14-asas-pemungutan-pajak-menur ut-ahli.html. [ 2 Agustus 2018]

Kementrian Keuangan Republik Indonesia. Informasi APBN 2018 : Pemantapan Pengelolaan Fiskal Untuk Mengakselerasi Pertumbuhan Ekonomi Yang Berkeadilan. Direktorat Jenderal Anggaran : Jakarta

Nafia, Dina dan Sunandar. 2016. Analisis Perbedaan Penerimaan Pajak Penghasilan Sebelum dan Sesudah Kenaikan Penghasilan Kena Pajak (PTKP) Pada Kantor Pelayanan Pajak Tegal. SENIT, 170- 175

Nuritomo. 2008. Pengaruh Peningkatan Penghasilan Tidak Kena Pajak Studi Pada KPP Yogyakarta Satu. Jurnal e-Perpajakan

Republik Indonesia. 2007. Undang- Undang No. 28 Tahun 2007 tentang Perubahan Ketiga atas UU No. 6 tahun 1983 tentang Ketentuan Umum dan Tata Cara Perpajakan. Sekretariat Negara. Jakarta

Republik Indonesia. 2008. Undang- Undang No.36 Tahun 2008 tentang Perubahan Keempat Atas Undang- Undang No 7 Tahun 1983 tentang Pajak Penghasilan. Sekretariat Negara. Jakarta

Republik Indonesia. 2015. Peraturan Direktur Jenderal Pajak Nomor PER-16/PJ/2016 tentang Pedoman Teknis Tata Cara Pemotongan, Penyetoran, dan Pelaporan Pajak Penghasilan Pasal 21 Dan/Atau Pajak Penghasilan Pasal 26 Sehubungan Dengan Pekerjaan, Jasa Dan Kegiatan Orang Pribadi. Direktorat Jenderal Pajak. Jakarta

Republik Indonesia. 2016. Peraturan Menteri Keuangan Nomor 101/PMK.010/2016 tentang Penyesuaian Besaran Penghasilan Tidak Kena Pajak. Departemen Keuangan. Jakarta

Republik Indonesia. 2014. Peraturan Menteri Keuangan Nomor 243/PMK.03/2014 tentang Surat Pemberitahuan Pajak. Departemen Keuangan. Jakarta

Republik Indonesia. 2017. Peraturan Menteri Keuangan Nomor 116/PMK.010/2017 tentang Barang Kebutuhan Pokok Yang Tidak Dikenai Pajak Pertambahan Nilai. Departemen Keuangan. Jakarta

Republik Indonesia. 2017. Undang-Undang No. 15 Tahun 2017 tentang Anggaran Pendapatan dan Belanja Negara Tahun Anggaran 2018. Sekretariat Negara. Jakarta

Sugiyono. 2012. Metode Penelitian Administrasi Dilengkapi Dengan Metode R\&D. Bandung : Penerbit Alfabeta

Sukmadinata, Nana Syaodih. 2011. Metode Penelitian. Bandung : PT Remaja Rosdakarya

Wicaksono, Pebrianto Eko. 2017. Sri Mulyani : Pungutan Pajak Harus Berasas Keadilan. Tersedia : http://m.liputan6.com/amp/2935030/sri-mulyani-pungutan-pajak-harusberasas-keadilan. [ 2 Agustus 2018]

Wijiraharjo. 2008. Asas-Asas Pemungutan Pajak. Tersedia : https://wijiraharjo.wordp ress.com/2008/02/02/asas-asas-pemungutan-pajak. [ 1 Agustus 2018]

Wulandari, Rizki. 2015. Faktor-Faktor yang Mempengaruhi Penerimaan Pajak Penghasilan pada KPP Pratama. Perbanas Review, 1, 87- 106 